\section{A new direction for HUGO}

\section{Washington}

WALTER Bodmer, director of research at the Imperial Cancer Research Fund in Britain, was elected last week to replace Victor McKusick of the Johns Hopkins Medical School as president of the Human Genome Organisation (HUGO). The hope is that Bodmer will provide the leadership and political acumen necessary to inject some life into HUGO, which has come under fire for being slow and ineffective.

HUGO was launched a year ago to coordinate international efforts to map and sequence the human genome but has made little progress towards raising the several million dollars a year needed to support its activities. It now has only $\$ 25,000$ in the bank. The best prospect for immediate funding appears to be the Howard Hughes Medical Institute, which is considering making a donation of about $\$ 1$ million now that HUGO has acquired status as a charitable foundation in Europe and the United States. Initial hopes that HUGO would receive government funds have so far come to nothing and charitable institutions are being looked to for early support.

Bodmer rejects criticisms of HUGO, insisting that there has been "a lot going on behind the scenes" over the past year. While he is president, HUGO's main office will be in London - when the money can be raised to pay for it. The Wellcome Trust is one possible source of support. Other HUGO offices are planned for Washington and Tokyo. Later, there might also be an office in Moscow.

As well as a human genome workshop

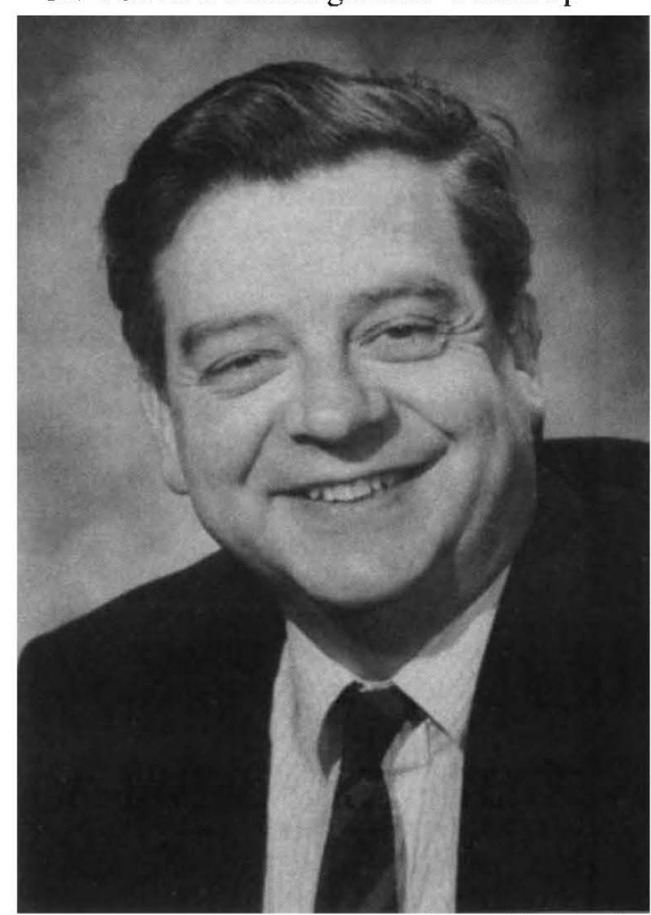

Walter Bodmer: office hunting in Central London?

724 to be held in Oxford, HUGO will next year carry out a study of the ethical, legal and social implications of the human genome project under the direction of McKusick. The study will be similar to that being carried out by the US National Institutes of Health (NIH) human genome office but will bring together the views of different countries and different cultures, says Bodmer.

A main aim of $\mathrm{HUGO}$ is to encourage international collaboration and the unrestricted exchange of data from the human genome project, an aim somewhat at odds with the views of council member James D. Watson, who heads the NIH

\section{Tokyo}

ON 1 December, Japan's molecular biologists debated their role in the human genome project at the annual meeting of the Molecular Biology Society of Japan in Sendai. It was the first public debate of a major science project by Japanese scientists and comes at a time when Japan has been criticized by Nobel prize winner James Watson for an apparent failure to commit sufficient funds to the international project (Nature 342, 463; 1989). The debate revealed the anxieties of some scientists and a growing rift between Japan's leading molecular biologists over which government agency should lead the project.

Kenichi Matsubara, Japan's representative and vice-president of the Human Genome Organization (HUGO), opened the debate by describing the goals of the project and its present status in Japan. Then Michio Oishi, another member of HUGO, voiced some of the concerns of society members. The debate was then opened to the floor.

Michio Oishi, a member of the international HUGO committee, says that MESC officials have given him no clear answer on whether the project will have an effect on other research funds. Oishi stresses that he is a supporter of the project. But it his personal opinion that the project has many technological aspects and should be led by the Ministry of International Trade and Industry (MITI) or some other technology-oriented agency rather than MESC. He feels that Japan's greatest contribution can be made in the area of robotics and sequencing technology rather than in the area of basic biological research, such as cloning where he says the United States is far ahead.

genome office and advocates that data should be kept from countries that do not contribute to the project. Bodmer is quick to point out that Watson is not an active council member and his views do not represent the views of HUGO. Bodmer says that even if restrictions on access to data were desirable, there is no way they could be enforced.

Two new vice-presidents were also elected at HUGO's council meeting last week in Bethesda, Maryland: Charles Cantor, head of the genome programme at Lawrence Berkeley Laboratory and Andre Mirzabekov of the Academy of Sciences of the USSR. Kenichi Matsubara of Osaka University in Japan will serve as the third vice-president for another year.

Chrlstine McGourty

\title{
Japan still seeking a role
}

But Kenichi Matsubara, vice president and Japanese representative of HUGO, says that he is "optimistic" that the human genome project will provide MESC with an opportunity to re-evaluate its system for supporting research and it will not necessarily drain off funds for other subject areas. Matsubara heads a MESC taskforce on the project. He fully recognizes, however, that the project must be an inter-ministry and inter-agency effort. And, earlier this year, he suggested that an "invisible" committee of scientists, like the MESC taskforce, could play a coordinating role (see Nature 339, 648; 1989).

The taskforce was recently established by MESC with about $¥ 600$ million ( $\$ 4$ million) to set up a project over the next two years (Nature 340, 667; 1989). Long before this, in the early 1980 s, the Science and Technology Agency (STA) began investing about a million dollars a year in the development of automatic DNA sequencing machines in a collaborative programme with industry (Nature 325, $771 ; 1987)$ and STA is now directing about the same amount into projects at the agency's Institute of Physical and Chemical Research (RIKEN) to sequence a small yeast chromosome and to map and eventually sequence human chromosome 21. STA this year also launched the Genosphere Project under the auspices of its ERATO programme which will provide a few million dollars a year to genomerelated research (Nature 339, 572; 1989).

The Ministry of Agriculture, Forestry and Fisheries has a tiny project to sequence the rice genome (Nature 340, 491; 1989). The Ministry of Health and Welfare has requested about $\$ 2$ million for next fiscal year to sequence genes that cause human disease. And other ministries are soon expected to initiate genome projects.

Some of those attending the meeting NATURE - VOL $342 \cdot 14$ DECEMBER 1989 